\title{
Effect of some Cultural Treatments, Elemental Sulfur Application and N-fertilization Levels on the Productivity of Maize and Fertility of Calcareous Sandy Soil
}

\author{
Hassanein, G.H. ${ }^{1}$; M.M. El-Dsouky ${ }^{1}$; M.M.M. Ahmed ${ }^{2}$ and \\ M.M.A.A. Zahran ${ }^{2 *}$ \\ ${ }^{1}$ Department of Soils \& Water, Faculty of Agric., Assiut Univ., Egypt. \\ ${ }^{2}$ Soils, Water and Environment Res. Institute, A. R. C., Giza, Egypt. \\ *Corresponding author: Mostafazahran80@yahoo.com
}

Received on: $6 / 11 / 2016$

Accepted for publication on: 21/11/2016

\begin{abstract}
The aim of the present investigation was to improve the productivity of calcareous sandy soil of Arab El-Awammer Experimental Station, Assiut governorate, Egypt. For this purpose a field experiment under minimum soil tillage conditions in summer season of 2010 was conducted in split split plot design with three replicates to detect the production of maize and soil fertility as influenced by previous and immediately some soil cultural treatments in main plot, levels of powder elemental S (zero and $300 \mathrm{~kg} \mathrm{~S} / \mathrm{fed}$ ) in the sub plots and mineral nitrogen fertilization levels (120 and $180 \mathrm{~kg} \mathrm{~N} / \mathrm{fed}$ ) in the sub sub plots. The four soil cultural treatments in main plots were two different crop sequences with crop residues completely removed (-CR) or with crop residues incorporated in soil surface layer $0-25 \mathrm{~cm}(+\mathrm{CR})$. The different two crop sequences (depend on it's inclusions from legume crop) were:-

$\begin{array}{cccc}\text { Year } & 2009 & 2010 & \text { legume crop } \%\end{array}$

Sequence $1=$ wheat - maize - wheat $-\underline{\text { maize }} \quad(0 \%)$

Sequence 2 = wheat - maize - clover $-\underline{\text { maize }} \quad(25 \%)$

The obtained results from the maize crop cultivated in season four of this study show that, crop residues applied in legume cereal cropping systems $(25 \%$ legume crops) resulted in higher maize growth, yields, yields components, NP uptake by maize plants and improved soil fertility (soil organic matter content, soil total $\mathrm{N}$, soil available $\mathrm{P}$ and soil $\mathrm{pH}$ ). Powdered elemental $\mathrm{S}$ applied seasonally at a level of $300 \mathrm{~kg} \mathrm{~S} / \mathrm{fed}$ and $\mathrm{N}$-fertilizer at the high levels $(180 \mathrm{~kg} \mathrm{~N} / \mathrm{fed})$ were also efficient in improving maize productivity and improving fertility status of calcareous sandy soil. The study recommends that seasonally application of crop residues in legume cereal cropping systems with seasonally application of powdered elemental $\mathrm{S}$ at a level of $300 \mathrm{~kg} \mathrm{~S} /$ fed and $\mathrm{N}$-fertilizer at the height levels $(180 \mathrm{~kg} \mathrm{~N} / \mathrm{fed})$ is the best treatment for producing high production of maize crop and improving fertility status of calcareous sandy soil.
\end{abstract}

Keywords: Crop sequence, Crop residues, Elemental sulfur, $N$-fertilization, Maize productivity, Sandy calcareous soil.

\section{Introduction}

In Egypt, the calcareous soils constitute about $25-30 \%$ of the total area (Abo-Elela, 2002). The following approaches are often applied for conservation agriculture as well as improving calcareous soil physicochemical characteristics, plant growth and productivity of planted crops: (1) Use minimum tillage (2) Use of good 
crop rotation or crop sequences (2) Application of organic materials or crop residues (3) Supplementation and management of nitrogen and other nutrients (4) Application of sulfur or other acidifiers for partially neutralizing the $\mathrm{CaCO}_{3}$ present in soil (Ali, 2008; Dendooven et al., 2012).

Abd El-Halim et al. (2001) reported that productivity of peanut, soybean, maize and pearlmillet in summer season were much higher following clover or lentil than after wheat or barley.

Crop residues are the parts of plants left in the field after crops have been harvested and threshed. The total yield of agricultural residues in Egypt has been as much as 24 millions tons per year, which is equivalent to 120 million $\mathrm{kg} \mathrm{N}, 130$ millions $\mathrm{kg} \mathrm{P}$, and 1,300 million $\mathrm{kg} \mathrm{K}$. of the used crop residues in the field which not only enhanced the content of organic matter in soil and increased the crop production, but also decreased the total amounts of chemical fertilizer consumption, as well as the environmental concerns (Safwat et al., 2003).

Elemental $\mathrm{S}$ is the most effective soil acidifier; and finely ground elemental $\mathrm{S}$ is converted quickly to $\mathrm{H}_{2} \mathrm{SO}_{4}$ in the soil through microbial action (Imas and Sheva, 2000). So, Many investigators (Attia and ElDsouky, 1996; Heydarnezhad et al. 2012) reported changes produced by addition of elemental sulfur to calcareous soils as it decreased soil $\mathrm{pH}$ and increased availability of $\mathrm{P}, \mathrm{Fe}$, $\mathrm{Mn}, \mathrm{Zn}$ and $\mathrm{Cu}$.

On sandy soil, Hassanein et al. (2007) reported that the highest nitrogen level $(180 \mathrm{~kg} / \mathrm{fed})$ applied to the maize hybrid Single Cross 10 gave the significantly highest grain yield, straw yield and biological yield.

The objective of this study was to examine the impact effect of crop sequence \& crop residues as a soil cultural treatment, S-application and $\mathrm{N}$-fertilizer levels on the productivity of maize crop grown on sandy calcareous soil.

\section{Materials and Methods}

\section{Site and experimental description}

Field experiment in summer season of 2010 in split spit plot design with thee replicates was conducted under minimum soil tillage conditions at Arab El-Awammer Research Station, Agric Res. Center (ARC)., Assiut Governorate, Egypt to detect the production of maize and soil fertility as influenced by previous and immediately soil cultural treatments in main plot, levels of powder elemental S (zero and $300 \mathrm{~kg} \mathrm{~S} / \mathrm{fed}$ ) in the sub plots and mineral nitrogen fertilization levels $(120$ and $180 \mathrm{~kg}$ $\mathrm{N} /$ fed) in the sub sub plots. The four soil cultural treatments in main plot were two different crop sequences with crop residues completely removed (-CR) or with crop residues incorporated in soil surface layer $0-25$ $\mathrm{cm}(+\mathrm{CR})$. The different two sequences (depend on it's inclusions from legume crop) were:-

\begin{tabular}{ll} 
Year $\quad 2009 \quad 2010 \quad$ legume crop $\%$ \\
\hline Sequence $1=$ wheat - maize - wheat - maize & $(0 \%)$ \\
Sequence $2=$ wheat - maize - clover - maize & $(25 \%)$
\end{tabular}

The soil of the experimental site is calcareous sandy and it is classified as typic torripsamments. The important physical and chemical characteristics of representative soil samples from the surface $(0-25 \mathrm{~cm})$ layers of the field experimental site are shown in Table (1). 


\section{Treatments description}

Under sprinkler irrigation system on fallow soil, two field experimental seasons in 2009 (winter and summer seasons) was carried out in split plot design $(4 \times 2$ factorial $)$ with three replicates to test the response of crops to soil cultural treatments (integration between crop sequence and crop residues) and sulfur application. But in the third and fourth seasons, two N-fertilizer levels were applied as a new factor in sub sub plots. Hence the experimental design was split split plot design $(4 \times 2 \times 2$ factorial) with three replicates area of each was $1 / 350$ feddan $\left(3 \mathrm{~m} \times 4 \mathrm{~m}=12 \mathrm{~m}^{2}\right)$. At harvest the aboveground residues of all crops were completely removed from the experimental plots and chopped into short pieces (approximatily $3-8 \mathrm{~cm}$ pieces). Soil was ploughed by chisel plough (minimum tillage) then divided into experimental plots and before cultivating the next crop in crop sequences by 14 to 18 day, the chopped crop residues of the previous crop was spreader on the plots and incorporated with the surface layer manually (+ CR) or not ($\mathrm{CR})$.

Table 1. Physical and chemical characteristics of representative soil samples from the field experimental site of the surface layer $(0-25 \mathrm{~cm})$.

\begin{tabular}{|c|c|c|}
\hline Soil Properties & Unit & Values \\
\hline \multicolumn{3}{|l|}{ Particle size distribution } \\
\hline Sand & $(\%)$ & 91.10 \\
\hline Silt & $(\%)$ & 5.65 \\
\hline Clay & $(\%)$ & 3.25 \\
\hline Texture grade & & Sandy \\
\hline \multicolumn{3}{|l|}{ Physical properties } \\
\hline Saturation & $\%(\mathrm{w} / \mathrm{w})$ & 22.9 \\
\hline Field capacity & $\%(\mathrm{w} / \mathrm{w})$ & 10.6 \\
\hline Wilting point & $\%(\mathrm{w} / \mathrm{w})$ & 4.3 \\
\hline Organic matter & $(\%)$ & 0.57 \\
\hline Total $\mathrm{CaCO}_{3}$ & $(\%)$ & 31.9 \\
\hline \multicolumn{3}{|l|}{ Chemical properties } \\
\hline $\mathrm{pH}\left(1: 1\right.$ water suspension) ${ }^{* * *}$ & & 8.35 \\
\hline EC $(1: 1$ extract $)$ & $\mathrm{dS} / \mathrm{m}$ & 0.53 \\
\hline Total nitrogen & $(\%)$ & 0.013 \\
\hline Available-P & $(\mathrm{mg} / \mathrm{kg})$ & 8.50 \\
\hline Available-K & (meq/100g soil) & 0.13 \\
\hline
\end{tabular}

*Each value represents the mean of three replications

${ }^{* *}$ Each value of $\mathrm{pH}$ (negative logarithmic value) converts to the original value by antilog equation to estimate the mean of three replications and converts again to $\mathrm{pH}$ value.

The experimental soil was irrigated by small quantity of irrigation water every 3 days until cultivating the next crop. The chopped crop residues were applied at rates of 3.4, 3.6 and 1.8 ton fed $^{-1}$ from wheat, maize and Egyptian clover (fourth cut) straw residues respectively.

In the sub plots; elemental $\mathrm{S}$ at tested levels (zero and $300 \mathrm{~kg}$ powder 
$\mathrm{S} /$ fed) were broadcasted and thoroughly mixed with the surface soil layer $(0-25 \mathrm{~cm})$ every season before cultivating the next crop. In the sub sub plots nitrogen fertilizer as ammonium nitrate $(33.5 \% \mathrm{~N})$ at tested levels (low and high) was used. The low $\mathrm{N}$ fertilizer for the different crops were 60,120 and $15 \mathrm{~kg} \mathrm{~N} /$ fed while the high $\mathrm{N}$ fertilizer were 120,180 and $45 \mathrm{~kg} \mathrm{~N} /$ fed for wheat, maize and clover, respectively.

\section{Maize cultivated in summer season of 2010}

The chopped crop residues of the previous crop were spreaded over the plots and manually incorporated with the surface layer of the soil (+ $\mathrm{CR})$ to be compared with plots without crop residues (-CR). Before sowing maize granular superphosphate $\left(15.5 \% \mathrm{P}_{2} \mathrm{O}_{5}\right)$ at a rate of $200 \mathrm{~kg} / \mathrm{fed}$, and elemental $\mathrm{S}$ at the tested level (zero and $300 \mathrm{~kg}$ powder $\mathrm{S} /$ fed) were broadcasted and thoroughly mixed with soil surface layer $(0-25 \mathrm{~cm})$. Maize seeds (Zea mays L. cv. single hybrid 10) were planted in $29^{\text {th }}$ May by drilling 2 - 4 seeds in each hill 4-5 $\mathrm{cm}$ deep, $20 \mathrm{~cm}$ apart and $60 \mathrm{~cm}$ distance between rows. After two weeks from sowing; seedlings were thinned to 2 plants /hill and after three weeks seedlings were thinned to 1 plants /hill. Ammonium nitrate $(33.5 \% \mathrm{~N})$ was added at the tested levels (120 and $180 \mathrm{~kg} \mathrm{~N} / \mathrm{fed}$ ), $8 \mathrm{~kg} \mathrm{~N} / \mathrm{fed}$ was broadcasted after 4 days from sowing and the rest of $\mathrm{N}$ fertilizer was added in six equal doses, after $14-28$ - 35 42,49 and 54 days from sowing. Potassium sulfate $\left(48 \% \quad \mathrm{~K}_{2} \mathrm{O}\right)$ was, added at a rate of $50 \mathrm{~kg} /$ fed in two equal doses after 42 and 54 days from sowing. Chelated Fe, Mn and $\mathrm{Zn}$ in liquid solution, containing $200 \mathrm{ppm}$ of each was used as foliar spray at a rate of $300 \mathrm{~L} / \mathrm{fed}$, sprayed twice after 30 and 50 days from sowing.

\section{Plant sampling for growth meas- urements}

Three random plant samples were taken from each plot at blooming start in 62 days after sowing. Plants height $(\mathrm{cm})$, shoot fresh weights were immediately determined, then plants were dried at $70{ }^{\circ} \mathrm{C}$ and their dry weights were determined.

Measurements of yield and yield components

At harvest (after 115 days from sowing), total yield of each plot was manually harvested, dried for 2 weeks and weighted. After threshing grain weights were determined, then total grain, straw yields per feddan and seed index were calculated. Samples of grains were taken from each plot for chemical analysis.

\section{Soil sampling}

After harvesting; soil of each plot was sampled. From each plot, 2 random soil cores were taken $(0-25$ $\mathrm{cm}$ depth). Soil cores were thoroughly mixed, air-dried and ground to pass a 2-mm sieve and stored for analysis.

\section{Soil analysis}

At the beginning of the study, soil mechanical analysis was carried out using pipette method according to Klute (1986). Water saturation, field capacity and wilting point were determined according to Klute (1986). Organic matter content, total $\mathrm{CaCO}_{3}$, soil $\mathrm{pH}$, electrical conductivity, total nitrogen, available phosphorus and potassium were determined according to Jackson (1973). 
Analysis of plants and crop residues

Plant samples and crop residues were digested according to Parkinson and Allen, 1975. The digested materials were subjected to analysis for the determinations of total $\mathrm{N}$ by micro-kjeldahl procedure, total $\mathrm{P}$ was determined coloremetrically by the stannous chloride phosphomolybdicsulfuric acid method and total $\mathrm{K}$ was determined by the flame photometric method according to Jackson (1973).

The results of chemical analysis of the residues of wheat, clover and maize are shown in Table (2).

Table 2. Chemical analyses of crop residues for wheat, clover and maize that was used in the experiment.

\begin{tabular}{|l|c|c|c|}
\hline \multirow{2}{*}{ Properties of Crop Residue } & \multicolumn{3}{|c|}{ Values* } \\
\cline { 2 - 4 } & $\begin{array}{c}\text { Wheat } \\
\text { residues }\end{array}$ & $\begin{array}{c}\text { Clover } \\
\text { residues }\end{array}$ & $\begin{array}{c}\text { Maize } \\
\text { residues }\end{array}$ \\
\hline Organic matter (\%) & 60.3 & 68.1 & 63.6 \\
\hline Organic carbon (\%) & 35.0 & 39.5 & 36.9 \\
\hline Total N (\%) & 0.36 & 1.77 & 0.58 \\
\hline C/ N ratio & 97.2 & 22.4 & 63.6 \\
\hline Total P (\%) & 0.07 & 0.16 & 0.08 \\
\hline Total K (\%) & 1.89 & 1.81 & 1.90 \\
\hline
\end{tabular}

*Each value represents the mean of crop residues analyses of different seasons

\section{Statistical analysis}

All obtained data were subjected to statistical analysis of variance and treatment means were compared for significant differences using the LSD at $p=0.05$. The MSTAT-C computer program was used to perform all the analysis of variance in agreement with the procedure outlined by Steel and Torrie (1982).

\section{Results and Discussion}

The data obtained on maize growth at 62 days, yield and yield components are shown in Tables $(3,4$ and 5). Also, the data obtained on soil properties after harvesting maize 2010 are shown in Table (6).

Maize growth parameters

Maize plant fresh and dry weights (g)

Data illustrated in Table (3) show that maize fresh and dry weights obtained from the plant samples at plant bloom (62 days from sowing) were increased significantly due to different soil cultural treatments. 
Table 3. Effect of soil cultural treatment, sulfur application and $\mathbf{N}$-fertilizer levels on maize growth at bloom day in summer season of 2010.

\begin{tabular}{|c|c|c|c|c|c|c|c|c|c|c|}
\hline \multicolumn{2}{|c|}{$\begin{array}{l}\text { Soil Cultural and } \\
\text { Sulfur Treatments }\end{array}$} & \multicolumn{3}{|c|}{\begin{tabular}{|c} 
Average Fresh Weights of \\
3 Plants(g)
\end{tabular}} & \multicolumn{3}{|c|}{$\begin{array}{c}\text { Average Dry Weights of } \\
3 \text { Plants(g) } \\
\end{array}$} & \multicolumn{3}{|c|}{$\begin{array}{c}\text { Average Heights of } 3 \\
\text { Plants (cm) }\end{array}$} \\
\hline \multirow{2}{*}{ Soil Cultural } & \multirow{2}{*}{$\begin{array}{l}\text { Sulfur } \\
\mathrm{kg} / \text { fed }\end{array}$} & \multicolumn{2}{|c|}{$\mathrm{N} \mathrm{kg/fed}$} & \multirow{2}{*}{ Mean } & \multicolumn{2}{|c|}{$\mathrm{N} \mathrm{kg} / \mathrm{fed}$} & \multirow{2}{*}{ Mean } & \multicolumn{2}{|c|}{$\mathrm{N} \mathrm{kg} / \mathrm{fed}$} & \multirow{2}{*}{ Mean } \\
\hline & & 120 & 180 & & 120 & 180 & & 120 & 180 & \\
\hline \multirow{2}{*}{ Sequence 1} & 0 & 621 & 673 & 647 & 107.6 & 108.7 & 108.2 & 214 & 222 & 218 \\
\hline & 300 & 614 & 705 & 659 & 109.7 & 112.4 & 111.1 & 230 & 229 & 230 \\
\hline \multicolumn{2}{|c|}{ Mean } & 617 & 689 & 653 & 108.7 & 110.6 & 109.6 & 222 & 226 & 224 \\
\hline \multirow{2}{*}{$\begin{array}{l}\text { Sequence } 1 \\
\quad+\text { CR }\end{array}$} & 0 & 754 & 785 & 770 & 121.6 & 130.3 & 125.9 & 224 & 231 & 228 \\
\hline & 300 & 823 & 903 & 863 & 144.4 & 148.6 & 146.5 & 241 & 239 & 240 \\
\hline \multicolumn{2}{|c|}{ Mean } & 788 & 844 & 816 & 133.0 & 139.4 & 136.2 & 233 & 235 & 234 \\
\hline \multirow{2}{*}{ Sequence 2} & 0 & 679 & 629 & 654 & 106.2 & 114.6 & 110.4 & 224 & 224 & 224 \\
\hline & 300 & 664 & 784 & 724 & 118.7 & 134.3 & 126.5 & 238 & 236 & 237 \\
\hline \multicolumn{2}{|c|}{ Mean } & 672 & 707 & 689 & 112.4 & 124.5 & 118.5 & 231 & 230 & 231 \\
\hline \multirow{2}{*}{$\begin{array}{l}\text { Sequence } 2 \\
\quad+C R\end{array}$} & 0 & 751 & 961 & 856 & 127.4 & 168.3 & 147.8 & 253 & 255 & 254 \\
\hline & 300 & 855 & 1011 & 933 & 148.7 & 168.5 & 158.6 & 253 & 254 & 254 \\
\hline \multicolumn{2}{|c|}{ Mean } & 803 & 986 & 895 & 138.0 & 168.4 & 153.2 & 253 & 254 & 254 \\
\hline \multirow{2}{*}{$\begin{array}{l}\text { Mean } \\
\mathbf{S} \times \mathbf{N}\end{array}$} & 0 & 701 & 762 & 732 & 115.7 & 130.5 & 123.1 & 229 & 233 & 231 \\
\hline & 300 & 739 & 851 & 795 & 130.4 & 140.9 & 135.6 & 241 & 240 & 240 \\
\hline \multicolumn{2}{|c|}{ Mean } & 720 & 806 & 763 & 123.0 & 135.7 & 129.4 & 235 & 236 & 236 \\
\hline \multirow{7}{*}{ LSD 0.05} & $\mathrm{C}$ & & 35.3 & & & 10.76 & & & 15.4 & \\
\hline & $\mathbf{S}$ & & 31.9 & & & 4.33 & & & n.s & \\
\hline & $\mathrm{C} \times \mathrm{S}$ & & n.s & & & 8.67 & & & n.s & \\
\hline & $\mathbf{N}$ & & 52.1 & & & 6.96 & & & n.s & \\
\hline & $\mathrm{C} \times \mathrm{N}$ & & n.s & & & 13.92 & & & n.s & \\
\hline & $\mathrm{S} \times \mathrm{N}$ & & n.s & & & n.s & & & n.s & \\
\hline & $\mathrm{C} \times \mathrm{S} \times \mathrm{N}$ & & n.s & & & n.s & & & n.s & \\
\hline
\end{tabular}

Sequence $1=$ continuous cereal crops (wheat and maize), Sequence $2=$ three seasons cereal crops followed by one season legume crop (clover), $+\mathrm{CR}=$ every season crop residues of previous crop incorporated in surface soil layer.

The plant fresh and dry weights varied between 653 and $109.6 \mathrm{~g}$, respectively in sequence 1 to 895 and $153.2 \mathrm{~g}$, respectively in sequence $2+$ CR (Table 3). Moreover, there were significant increases in plant fresh and dry weights at plant bloom as a result of crop residues incorporated in soil surface layer in crop sequence 1 and 2 as compared with the same treatment but with crop residues completely removed (crop sequence 1 and 2 respectively).

The results of this field experiment are in agreement with those of other investigators indicating the positive effects of crop residues on plant growth and yield of many crops especially under newly reclaimed soil conditions (kumar and Prasad 2014;
Monsefi et al., 2014; Sepahvand and Mehranzadeh, 2013; Soleymani et al., 2016).

On the other hand, calculating the average of two crop sequences regardless crop residues effect, the obtained data indicated that, cultivating $25 \%$ from crops by legume crop improvement maize plant growth as compared with continues cereal crops (Table 3).

Sulfur application seasonally, at the rate of $300 \mathrm{~kg} / \mathrm{fed}$, induced significant improvement in maize growth parameters (plant fresh and dry weights). Increasing Nfertilization levels from 120 to $180 \mathrm{~kg}$ $\mathrm{N} /$ fed caused significant increases in maize growth parameters (plant fresh and dry weights). 
The results presented in Table (3) show two significant interactions on maize plant dry weight at plants bloom, the first interaction between soil cultural treatments \& Sapplication, and the second interaction between soil cultural treatments and $\mathrm{N}$-fertilizer levels. In this respect Attia and El-Dsouky, (1996) reported that the best synergetic effect for wheat plants grown on sandy calcareous soil was obtained by combined of those treatment, $30 \mathrm{~m}^{3}$ organic manure +1 ton $\mathrm{S}$ with inoculation +120 $\mathrm{kg} \mathrm{N} /$ fed.

\section{Maize plant height $(\mathrm{cm})$}

Maize plant height obtained from the plant samples at plant bloom (62 days from sowing) was increased significantly due to different soil cultural treatments. The plant height varied from $224 \mathrm{~cm}$ in sequence 1 to 254 $\mathrm{cm}$ in sequence $2+\mathrm{CR}$ (Table 3 ). This agrees with the results obtained by Rahman (2004); Verma and Pandey (2013). They reported that crop residues have positive effect on wheat yield and plant height.

\section{Maize grain yield, straw yield and biological yield (kg/fed)}

Data illustrated in Table (4) show that maize yield and yield components (grain yield, straw yield and biological yield) were increased significantly due to different soil cultural treatments.

The results in Table (4) reflect great differences in response of maize yield to the soil cultural treatments. The obtained values of maize yield components could be descendingly ranked in the following older; The sequence $2+$ crop residues came in the first rank recording the highest maize grain yield, straw yield and biological yield while sequence $1+$ crop residues was the second. The contentious cereal crop sequence came in the last rank. Also, treatment (sequence $2+$ crop residues) resulted in significant percent increases in grain yield, straw yield and biological yield estimated by $24.3 \%, 24.7 \%$ and $24.5 \%$, as compared with the control (contentious cereal crop sequence). While treatment (sequence $1+$ crop residues) resulted in significant increases in grain yield, straw yield and biological yield estimated by $13.5 \%$, $15.9 \%$ and $14.9 \%$ respectively as compared with control. Also, the increase in maize yield and yield components of treatment sequence $2+$ crop residues was significant as compared by treatment sequence $1+$ crop residues.

Furthermore, crop residues incorporated with soil resulted in $19.9 \%, 18.6 \%$ and $19.1 \%$ increases in grain yield, straw yield and biological yield of maize, respectively as compared with averages of crop residues completely removed. This probably happened due to more nutrients released from crop residues. These findings are in agreement with those of Javadianfar and Siadat (2013); Kravchenko and Thelen (2007); Soleymani et al. (2016).

On the other hand crop sequences had little effect on maize yield and yield components. Averages of crop sequence 1 were 2371, 3257 and $5628 \mathrm{~kg} /$ fed for grain, straw and biological yields, respectively. While averages of crop sequence 2 were 2471,3434 and $5905 \mathrm{~kg} /$ fed for grain, straw and biological yields, respectively. This estimated number means that, crop sequence 2 resulted 
only in $4.2 \%, 5.4 \%$ and $4.9 \%$ increases in grain, straw and biological yields, respectively compared with sequence1 without legume crops.

Sulfur application, at the rate of $300 \mathrm{~kg} /$ fed seasonally, induced sig- nificant improvement on maize yield and yield components parameters (grain, straw and biological yield) as compared with the zero S.

Table 4. Effect of soil cultural treatments, sulfur application and N-fertilizer levels on maize yield and yield components (2010).

\begin{tabular}{|c|c|c|c|c|c|c|c|c|c|c|c|c|c|}
\hline \multicolumn{2}{|c|}{$\begin{array}{l}\text { Soil cultural and } \\
\text { Sulfur Treatments }\end{array}$} & \multicolumn{3}{|c|}{$\begin{array}{l}\text { Grain Yield } \\
\text { kg/fed }\end{array}$} & \multicolumn{3}{|c|}{$\begin{array}{l}\text { Straw Yield } \\
\text { kg/fed }\end{array}$} & \multicolumn{3}{|c|}{$\begin{array}{l}\text { Biological Yield } \\
\text { (kg/fed) }\end{array}$} & \multicolumn{3}{|c|}{$\begin{array}{c}\text { Seed Index } \\
\text { (100 Grains/g) }\end{array}$} \\
\hline \multirow{2}{*}{ Soil Cultural } & \multirow{2}{*}{$\begin{array}{l}\text { Sulfur } \\
\mathrm{kg} / \mathrm{fed}\end{array}$} & \multicolumn{2}{|c|}{$\mathrm{N} \mathrm{kg} / \mathrm{fed}$} & \multirow{2}{*}{ Mean } & \multicolumn{2}{|c|}{$\mathrm{N} \mathrm{kg/fed}$} & \multirow{2}{*}{ Mean } & \multicolumn{2}{|c|}{$\mathrm{N} \mathrm{kg/fed}$} & \multirow{2}{*}{ Mean } & \multicolumn{2}{|c|}{$\mathrm{N} \mathrm{kg/fed}$} & \multirow{2}{*}{ Mean } \\
\hline & & 120 & 180 & & 120 & 180 & & 120 & 180 & & 120 & 180 & \\
\hline \multirow{2}{*}{ Sequence 1} & 0 & 1824 & 2198 & 2011 & 2427 & 3031 & 2729 & 4251 & 5229 & 4740 & 23.93 & 25.51 & 24.72 \\
\hline & 300 & 2364 & 2497 & 2431 & 3166 & 3445 & 3305 & 5530 & 5943 & 5736 & 25.99 & 26.03 & 26.01 \\
\hline \multicolumn{2}{|c|}{ Mean } & 2094 & 2348 & 2221 & 2796 & 3238 & 3017 & 4891 & 5586 & 5238 & 24.96 & 25.77 & 25.36 \\
\hline \multirow{2}{*}{$\begin{array}{l}\text { Sequence } 1 \\
+ \text { CR }\end{array}$} & 0 & 1962 & 2471 & 2216 & 2746 & 3432 & 3089 & 4708 & 5902 & 5305 & 25.22 & 27.13 & 26.18 \\
\hline & 300 & 2800 & 2854 & 2827 & 3785 & 4025 & 3905 & 6584 & 6880 & 6732 & 28.91 & 29.56 & 29.24 \\
\hline \multicolumn{2}{|l|}{ Mean } & 2381 & 2663 & 2522 & 3265 & 3729 & 3497 & 5646 & 6391 & 6019 & 27.07 & 28.35 & 27.71 \\
\hline \multirow{2}{*}{ Sequence 2} & 0 & 1857 & 2277 & 2067 & 2670 & 3185 & 2928 & 4527 & 5461 & 4994 & 23.32 & 27.20 & 25.26 \\
\hline & 300 & 2270 & 2326 & 2298 & 3224 & 3342 & 3283 & 5495 & 5668 & 5582 & 25.73 & 26.17 & 25.95 \\
\hline \multicolumn{2}{|c|}{ Mean } & 2064 & 2301 & 2183 & 2947 & 3263 & 3105 & 5011 & 5565 & 5288 & 24.52 & 26.69 & 25.61 \\
\hline \multirow{2}{*}{$\begin{array}{l}\text { Sequence } 2 \\
+ \text { CR }\end{array}$} & 0 & 2084 & 2916 & 2500 & 3099 & 4045 & 3572 & 5183 & 6961 & 6072 & 25.06 & 28.26 & 26.66 \\
\hline & 300 & 3018 & 3021 & 3020 & 3852 & 4056 & 3954 & 6870 & 7077 & 6974 & 29.85 & 29.43 & 29.64 \\
\hline \multicolumn{2}{|l|}{ Mean } & 2551 & 2969 & 2760 & 3475 & 4050 & 3763 & 6026 & 7019 & 6523 & 27.45 & 28.84 & 28.15 \\
\hline \multirow{2}{*}{$\begin{array}{l}\text { Mean } \\
\mathbf{S} \times \mathbf{N}\end{array}$} & 0 & 1932 & 2465 & 2199 & 2736 & 3423 & 3079 & 4667 & 5888 & 5278 & 24.38 & 27.03 & 25.70 \\
\hline & 300 & 2613 & 2675 & 2644 & 3507 & 3717 & 3612 & 6120 & 6392 & 6256 & 27.62 & 27.80 & 27.71 \\
\hline \multicolumn{2}{|l|}{ Mean } & 2272 & 2570 & 2421 & 3121 & 3570 & 3346 & 5394 & 6140 & 5767 & 26.00 & 27.41 & 26.71 \\
\hline \multirow{7}{*}{ LSD 0.05} & $\mathrm{C}$ & & 229.3 & & & 208.0 & & & 412.2 & & & 2.19 & \\
\hline & $\mathbf{S}$ & & 120.2 & & & 146.5 & & & 249.5 & & & 0.66 & \\
\hline & $\mathrm{C} \times \mathrm{S}$ & & n.s & & & n.s & & & n.s & & & 1.33 & \\
\hline & $\mathbf{N}$ & & 104.1 & & & 158.4 & & & 241.0 & & & 1.01 & \\
\hline & $\mathrm{C} \times \mathrm{N}$ & & n.s & & & n.s & & & n.s & & & $\mathrm{n} . \mathrm{s}$ & \\
\hline & $\mathrm{S} \times \mathrm{N}$ & & 147.3 & & & 316.8 & & & 340. & & & 1.42 & \\
\hline & $\mathrm{C} \times \mathrm{S} \times \mathrm{N}$ & & n.s & & & n.s & & & n.s & & & n.s & \\
\hline
\end{tabular}

Sequence $1=$ continuous cereal crops (wheat and maize), Sequence $2=$ three seasons cereal crops followed by one season legume crop (clover). $+\mathrm{CR}=$ every season crop residues of previous crop were incorporated in surface soil layer.

The results of this field experiment are in agreement with those of other investigators indicating that $\mathrm{S}$ application to soil, especially in powdered form or small sized particles is beneficial for enhancing plant growth as well as being good amendment for improving soil properties and productivity (Ali, 2008; Attia and ElDsouky, 1996).
Also, $\mathrm{N}$ levels at the rate of 180 $\mathrm{kg} \mathrm{N} / \mathrm{fed}$, induced significant improvement in all maize yield parameters as compared with $120 \mathrm{~kg} \mathrm{~N} / \mathrm{fed}$ (Table 4). Compared with $120 \mathrm{~kg}$ $\mathrm{N} /$ fed the increases in grain, straw and biological yields were $13.1 \%$ $14.4 \%$ and $13.8 \%$ respectively due to the higher rate of nitrogen $(180 \mathrm{~kg}$ $\mathrm{N} / \mathrm{fed}$ ). Results of this field experiment are in accordance with those of 
other investigators confirming the stimulative effect of increasing $\mathrm{N}$ fertilization, especially on newly cultivated soils with low O.M. for improvement of growth and yield of maize and wheat (Abd El-Qahar and Ahmad, 2016; El- Afandy et al., 2007; Hassanein et al., 2007).

Results presented in Table (4) show significant dual interactions between S-application and $\mathrm{N}$-fertilizer levels on maize grain yield, straw yield and biological yield. These results are similar to those reported by other investigators recording the synergetic improvements in maize yield observed by the combined application of S with N-fertilizer (Jaliya et al., 2016; Ray and Spider, 2000).

\section{Seed index (g)}

Data obtained regarding to seed index at harvest as influenced by soil cultural treatments (Table 4) indicated that, seed index (100 grains weight) was increased significantly due to different soil cultural treatments. The 100 grains weights varied from $25.4 \mathrm{~g}$ sequence 1 without crop residues to $28.2 \mathrm{~g}$ in sequence 2 with crop residues (Table 4).

Seasonally sulfur application, at the rate of $300 \mathrm{~kg} / \mathrm{fed}$ induced significant improvement in maize seed index at harvesting as compared with the zero $\mathrm{S}$ (Table 4). These results are in agreement with Ali, (2008).

On the other hand, N-fertilizer level, at the rate of $180 \mathrm{~kg} \mathrm{~N} / \mathrm{fed}$ induced significant increases in maize seed index at harvesting as compared with the $120 \mathrm{~kg} \mathrm{~N} /$ fed (Table 4).

The data also suggested that there are two significant interactions, the first between soil cultural treatments \& S-application, while the second significant interaction was between S-application and $\mathrm{N}$-fertilizer levels on maize seed index at final harvesting. This finding is agreed with Attia and El-Dsouky, 1996.

\section{$\mathbf{N}$ and $\mathbf{P}$ uptake by maize grains} (kg/fed)

It could be deduced form the data presented in Table (5) that $\mathrm{N}$ and $\mathrm{P}$ uptake by maize grain yield were significantly increased due to different soil cultural treatments. Nitrogen uptake by maize grain yield was almost similar with a value of 34.8 $\mathrm{kg} /$ fed in sequence 1 or sequence 2 without crop residues. Mean $\mathrm{N}$ uptake was increased to $45.0 \mathrm{~kg} / \mathrm{fed}$ in sequence 2 with crop residues. In the same time $\mathrm{P}$ uptake by maize grain yield varied from $8.1 \mathrm{~kg} / \mathrm{fed}$ in sequence 2 without crop residues to $11.1 \mathrm{~kg} /$ fed in sequence 2 with crop residues incorporated in soil surface layer. 
Table 5. Effect of soil cultural treatments, sulfur application and $\mathbf{N}$-fertilizer levels on $\mathbf{N} \& \mathbf{P}$ uptake by maize grain yield in summer season of 2010.

\begin{tabular}{|c|c|c|c|c|c|c|c|}
\hline \multicolumn{2}{|c|}{$\begin{array}{l}\text { Soil Cultural and } \\
\text { Sulfur Treatments }\end{array}$} & \multicolumn{3}{|c|}{$\begin{array}{c}\text { N uptake by Grains } \\
(\mathrm{kg} / \mathrm{fed})\end{array}$} & \multicolumn{3}{|c|}{$\begin{array}{c}\text { P uptake by Grains } \\
(\mathrm{kg} / \mathrm{fed})\end{array}$} \\
\hline \multirow{2}{*}{$\begin{array}{c}\text { Soil Cultural } \\
\text { Treatments }\end{array}$} & \multirow{2}{*}{$\begin{array}{l}\text { Sulfur } \\
(\mathrm{kg} / \mathrm{fed})\end{array}$} & \multicolumn{2}{|c|}{$\mathrm{N}(\mathrm{kg} / \mathrm{fed})$} & \multirow{2}{*}{ Mean } & \multicolumn{2}{|c|}{$\mathrm{N}(\mathrm{kg} / \mathrm{fed})$} & \multirow{2}{*}{ Mean } \\
\hline & & 120 & 180 & & 120 & 180 & \\
\hline \multirow{2}{*}{ Sequence 1} & 0 & 27.41 & 34.69 & 31.05 & 6.70 & 8.86 & 7.78 \\
\hline & 300 & 37.26 & 39.79 & 38.52 & 8.68 & 10.14 & 9.41 \\
\hline \multicolumn{2}{|c|}{ Mean } & 32.34 & 37.24 & 34.79 & 7.69 & 9.50 & 8.60 \\
\hline \multirow{2}{*}{$\begin{array}{l}\text { Sequence } 1 \\
+ \text { CR }\end{array}$} & 0 & 29.50 & 39.55 & 34.52 & 7.70 & 11.19 & 9.44 \\
\hline & 300 & 43.52 & 47.11 & 45.32 & 11.72 & 12.98 & 12.35 \\
\hline \multicolumn{2}{|c|}{ Mean } & 36.51 & 43.33 & 39.92 & 9.71 & 12.08 & 10.90 \\
\hline \multirow{2}{*}{ Sequence 2} & 0 & 29.09 & 36.69 & 32.89 & 6.63 & 8.45 & 7.54 \\
\hline & 300 & 35.62 & 37.80 & 36.71 & 8.31 & 9.00 & 8.66 \\
\hline \multicolumn{2}{|c|}{ Mean } & 32.35 & 37.24 & 34.80 & 7.47 & 8.73 & 8.10 \\
\hline \multirow{2}{*}{$\begin{array}{l}\text { Sequence } 2 \\
+\mathrm{CR}\end{array}$} & 0 & 33.62 & 47.40 & 40.51 & 7.98 & 11.79 & 9.89 \\
\hline & 300 & 48.59 & 50.21 & 49.40 & 11.89 & 12.74 & 12.32 \\
\hline \multicolumn{2}{|c|}{ Mean } & 41.11 & 48.81 & 44.96 & 9.94 & 12.27 & 11.10 \\
\hline \multirow{2}{*}{$\begin{array}{l}\text { Mean } \\
\mathbf{S} \times \mathbf{N}\end{array}$} & 0 & 29.91 & 39.58 & 34.74 & 7.25 & 10.07 & 8.66 \\
\hline & 300 & 41.25 & 43.73 & 42.49 & 10.15 & 11.22 & 10.68 \\
\hline \multicolumn{2}{|c|}{ Mean } & 35.58 & 41.65 & 38.62 & 8.70 & 10.64 & 9.67 \\
\hline \multirow{7}{*}{ LSD 0.05} & $\mathrm{C}$ & & 2.85 & & & 0.41 & \\
\hline & $\mathbf{S}$ & & 1.11 & & & 0.44 & \\
\hline & $\mathrm{C} \times \mathrm{S}$ & & 2.22 & & & 0.88 & \\
\hline & $\mathbf{N}$ & & 1.76 & & & 0.44 & \\
\hline & $\mathrm{C} \times \mathrm{N}$ & & n.s & & & n.s & \\
\hline & $\mathrm{S} \times \mathrm{N}$ & & 2.49 & & & 0.62 & \\
\hline & $\mathrm{C} \times \mathrm{S} \times \mathrm{N}$ & & n.s & & & n.s & \\
\hline
\end{tabular}

Sequence $1=$ continuous cereal crops (wheat and maize), Sequence $2=$ three seasons cereal crops followed by one season legume crop (clover), $+\mathrm{CR}=$ every season crop residues of previous crop were incorporated in surface soil layer.

Furthermore, significant increases in $\mathrm{N}$ and $\mathrm{P}$ uptake by maize grain yield were obtained as a result of crop residues incorporated in soil surface layer in crop sequence 1 and 2 as compared with its values with crop residues completely removed.
Also, crop residues incorporated in the soil resulted in $22.0 \%$, and $31.8 \%$ increases in $\mathrm{N}$ and $\mathrm{P}$ grain uptake. This probably happened due to the increases in nutrient availability in the soil as well as to the nutrients released from crop residues after de- 
composition. This finding is in agreement with those obtained by Mohammad et al., 2012; Zhang et al., 2016. They found that organic residues have been considered as the preferable nutrient source to improve fertilizer use efficiency. Combining $\mathrm{N}$ fertilizer with medium quality residues has the potential to change $\mathrm{N}$ transformations through a negative interactive effect on mineral N. Similarly, straw incorporation, in the soil resulted in an increase in microbial biomass and $\mathrm{N}$ mineralization (Singh, 1995), Furthermore Mohammad et al., 2010 and Safwat et al., 2003 reported that the possible reason for improvement $\mathrm{N}$ uptake by plant in no tillage with crop residues retained treatment might be due to lower soil surface temperature and water evaporation that might have helped to reduce the N-losses from fertilizer.

Sulfur application, at the rate of $300 \mathrm{~kg} \mathrm{~S} /$ fed, induced significant improvement and resulted in $22.31 \%$ and $23.33 \%$ increases in $\mathrm{N}$ and $\mathrm{P}$ uptake by maize grains as compared with the zero S (Table 5). These findings are in line with those of Ali, (2008) who observed that the $\mathrm{N}$ and $\mathrm{P}$ uptake by maize grains were affected significantly by S-application and Nfertilizer level. Also, Eisa et al. (2003) recorded that sulfur application exhibited a relatively high content of $\mathrm{N}, \mathrm{P}$ and $\mathrm{K}$ in maize grains and straw in calcareous soil.

Increasing $\mathrm{N}$-fertilizer level from 120 to $180 \mathrm{~kg} \mathrm{~N} /$ fed caused significant increases in $\mathrm{N}$ and $\mathrm{P}$ uptake by maize grain yield. These findings are in agreement with those obtained by Hassanein et al., 2007.
The results in Table (5) show two significant interactions, the first interaction between soil cultural treatments \& sulfur application and the second interaction was between sulfur application \& N-fertilizer levels on $\mathrm{N}$ and $\mathrm{P}$ uptake by maize grains. This may be due to the increase in available $\mathrm{N}$ and $\mathrm{P}$ in soil under regaining crop residues with $\mathrm{S}$ application and under high $\mathrm{N}$ fertilizer level with S-application. In this respect Attia and El- Dsouky, 1996 reported that the best synergetic effect for $\mathrm{N}$ uptake by wheat grown on sandy calcareous soil was obtained by combined of those treatments, 30 $\mathrm{m}^{3}$ organic manure +1 ton $\mathrm{S}$ with inoculation + the height fertilizer level of N, $120 \mathrm{~kg} \mathrm{~N} / \mathrm{fed}$.

\section{Soil properties after maize 2010 harvesting}

It is worth to mention that soil properties after maize yield of 2010 harvesting (soil organic content, soil total $\mathrm{N}$, soil available $\mathrm{P}$ and soil $\mathrm{pH}$ ) were improvement significantly due to different soil cultural treatments (Table 6).

Generally, incorporated of crop residues as soil cultural treatments with any crop sequences for many seasons before maize 2010 cultivated resulted in significant increases in soil organic content, soil total $\mathrm{N}$ and soil available $\mathrm{P}$ as compared with treatments cultivated with crop residues completely removed. Averages of this increases in soil organic content (\%), soil total $\mathrm{N}(\mathrm{ppm})$ and soil available $\mathrm{P}(\mathrm{ppm})$ were $0.16 \%, 122$ and $3.24 \mathrm{ppm}$, respectively (Table 6). This probably happened due to more nutrients release from crop residues. 
This finding is agreed with Ailincai et al., (2010); Ghimire et al., (2016).

On the other hand soil cultural treatments resulted in significant decreases in soil $\mathrm{pH}$ after maize 2010 harvesting. The best treatment in decreasing soil $\mathrm{pH}$ was sequence $2+$ crop residues which resulted in significant decreases between it and other treatments with crop residues completely removed. In this respect Huang et al. (2004); Millar and Baggs (2004), reported that, organic wastes can influence soil $\mathrm{pH}$ through accumulation of $\mathrm{CO}_{2}$ and organic acids during their decomposition in the soils.

Seasonally S-application at the rate of $300 \mathrm{~kg} /$ fed to soil affected soil properties as shown from the results presents in Table (6), in addition to inducing significant reduction in soil $\mathrm{pH}$, it resulted in significant increase in soil total $\mathrm{N}$ and soil available $\mathrm{P}$ at harvesting maize of 2010. Elemental sulfur can be oxidized by many soil microorganisms and forming sulfuric acid, consequently it react with soil $\mathrm{CaCO}_{3}$ resulting in $\mathrm{CaSO}_{4}$. The latter can be lonized to $\mathrm{Ca}^{2+}$ and $\mathrm{SO}^{2-}$, then $\mathrm{Ca}^{2+}$ can be improved soil aggregation and permeability and $\mathrm{SO}_{4}{ }^{-2}$ reduced soil $\mathrm{pH}$. Theses results are in agreement with those by Awadalla et al. (2003).

This probably happened due to more nutrients availability as a result of decreasing $\mathrm{pH}$ of sandy calcareous soil. This finding is agreed with Abdo et al., (2010); Heydarnezhad et al. (2012).

Data presented in (table 6) show that nitrogen fertilizer level at the rate of $180 \mathrm{~kg} \mathrm{~N} / \mathrm{fed}$, induced significant increase in soil total $\mathrm{N}$. This finding is agreed with Khadr et al., (2004). Also, Nitrogen fertilizer level at the rate of $180 \mathrm{~kg} \mathrm{~N} /$ fed induced significant decreases in soil $\mathrm{pH}$ as compared with $120 \mathrm{~kg} \mathrm{~N} /$ fed level. 
Table 6. Soil properties changes of maize crop as influenced by soil cultural treatments, sulfur application and $\mathbf{N}$-fertilizer levels during summer season of 2010

\begin{tabular}{|c|c|c|c|c|c|c|c|c|c|c|c|c|c|}
\hline \multicolumn{2}{|c|}{$\begin{array}{l}\text { Soil Cultural and } \\
\text { Sulfur Treatments }\end{array}$} & \multicolumn{3}{|c|}{$\begin{array}{c}\text { Soil Organic Mat- } \\
\operatorname{ter}(\%)\end{array}$} & \multicolumn{3}{|c|}{$\begin{array}{l}\text { Soil Total N } \\
\quad(\text { ppm) }\end{array}$} & \multicolumn{3}{|c|}{$\begin{array}{l}\text { Available } P \\
\quad(p p m)\end{array}$} & \multicolumn{3}{|c|}{$\begin{array}{c}\mathrm{pH} \\
\text { in }(1: 1) \text { soil } \\
\text { suspension }\end{array}$} \\
\hline \multirow{2}{*}{$\begin{array}{c}\text { Soil } \\
\text { Cultural } \\
\end{array}$} & \multirow{2}{*}{$\begin{array}{l}\text { Sulfur } \\
\mathrm{kg} / \text { fed }\end{array}$} & \multicolumn{2}{|c|}{$\mathrm{N} \mathrm{kg} / \mathrm{fed}$} & \multirow{2}{*}{ Mean } & \multicolumn{2}{|c|}{$\mathrm{N} \mathrm{kg} / \mathrm{fed}$} & \multirow{2}{*}{ Mean } & \multicolumn{2}{|c|}{$\mathrm{N} \mathrm{kg}$ /fed } & \multirow{2}{*}{ Mean } & \multicolumn{2}{|c|}{$\mathrm{N} \mathrm{kg} / \mathrm{fed}$} & \multirow{2}{*}{ Mean } \\
\hline & & 120 & 180 & & 120 & 180 & & 120 & 180 & & 120 & 180 & \\
\hline \multirow{2}{*}{ Sequence 1} & 0 & 0.87 & 0.85 & 0.86 & 470 & 497 & 484 & 7.81 & 8.40 & 8.10 & 8.15 & 8.07 & 8.11 \\
\hline & 300 & 0.87 & 0.87 & 0.87 & 503 & 513 & 508 & 8.99 & 9.47 & 9.23 & 7.97 & 7.82 & 7.90 \\
\hline \multicolumn{2}{|c|}{ Mean } & 0.87 & 0.86 & 0.86 & 486 & 505 & 496 & 8.40 & 8.93 & 8.67 & 8.06 & 7.95 & 8.00 \\
\hline \multirow{2}{*}{$\begin{array}{l}\text { Sequence } 1 \\
+\mathrm{CR}\end{array}$} & 0 & 1.00 & 1.05 & 1.02 & 569 & 609 & 589 & 10.96 & 11.54 & 11.25 & 8.07 & 8.01 & 8.04 \\
\hline & 300 & 1.01 & 1.04 & 1.02 & 619 & 647 & 633 & 12.00 & 12.94 & 12.47 & 7.72 & 7.66 & 7.69 \\
\hline \multicolumn{2}{|c|}{ Mean } & 1.00 & 1.05 & 1.02 & \begin{tabular}{|l|}
594 \\
\end{tabular} & 628 & 611 & 11.48 & 12.24 & 11.86 & 7.89 & 7.84 & 7.87 \\
\hline \multirow{3}{*}{ Sequence 2} & 0 & 0.84 & 0.85 & 0.84 & 489 & 502 & 495 & 7.30 & 7.46 & 7.38 & 8.11 & 8.02 & 8.07 \\
\hline & 300 & 0.86 & 0.82 & 0.84 & 512 & 542 & 527 & 7.97 & 8.57 & 8.27 & 7.86 & 7.68 & 7.77 \\
\hline & Mean & 0.85 & 0.84 & 0.84 & 501 & 522 & 511 & 7.64 & 8.02 & 7.83 & 7.98 & 7.85 & 7.92 \\
\hline \multirow{2}{*}{$\begin{array}{l}\text { Sequence } 2 \\
\quad+C R\end{array}$} & 0 & 1.00 & 1.01 & 1.01 & 603 & 631 & 617 & 10.04 & 10.61 & 10.33 & 7.97 & 7.85 & 7.91 \\
\hline & 300 & 0.96 & 1.00 & 0.98 & 610 & 638 & 624 & 11.49 & 12.34 & 11.92 & 7.74 & 7.66 & 7.70 \\
\hline \multicolumn{2}{|c|}{ Mean } & 0.98 & 1.01 & 0.99 & 606 & 634 & 620 & 10.77 & 11.47 & 11.12 & 7.85 & 7.75 & 7.80 \\
\hline \multirow{2}{*}{$\begin{array}{l}\text { Mean } \\
\mathbf{S} \times \mathbf{N}\end{array}$} & 0 & 0.92 & 0.94 & 0.93 & 533 & 560 & 546 & 9.03 & 9.50 & 9.26 & 8.07 & 7.99 & 8.03 \\
\hline & 300 & 0.93 & 0.93 & 0.93 & 561 & 585 & 573 & 10.11 & 10.83 & 10.47 & 7.82 & 7.71 & 7.76 \\
\hline \multicolumn{2}{|c|}{ Mean } & 0.93 & 0.94 & 0.93 & 547 & 572 & 560 & 9.57 & 10.17 & 9.87 & 7.95 & 7.85 & 7.90 \\
\hline \multirow{7}{*}{ LSD 0.05} & C & & 0.05 & & & 36. & & & 2.34 & & & 0.07 & \\
\hline & $\mathbf{S}$ & & n.s & & & 18.3 & & & 0.73 & & & 0.08 & \\
\hline & $\mathrm{C} \times \mathrm{S}$ & & n.s & & & $\mathrm{n.s}$ & & & n.s & & & n.s & \\
\hline & $\mathbf{N}$ & & n.s & & & 18. & & & n.s & & & 0.07 & \\
\hline & $\mathrm{C} \times \mathrm{N}$ & & n.s & & & n.s & & & n.s & & & n.s & \\
\hline & $\mathrm{S} \times \mathrm{N}$ & & n.s & & & n.s & & & n.s & & & n.s & \\
\hline & $\mathrm{C} \times \mathrm{S} \times \mathrm{N}$ & & n.s & & & n.s & & & n.s & & & n.s & \\
\hline
\end{tabular}

Sequence $1=$ continuous cereal crops (wheat and maize), Sequence $2=$ three seasons cereal crops followed by one season legume crop (clover), $+\mathrm{CR}=$ every season crop residues of previous crop incorporated in surface soil layer.

This may be due to the effect of ammonium fertilizer on lowering the soil $\mathrm{pH}$ during nitrification because protons are released in this process $\left(2 \mathrm{NH}_{4}^{+}+3 \mathrm{O}_{2} \longrightarrow 2 \mathrm{NO}_{3}^{-}+\right.$ $\left.8 \mathrm{H}^{+}\right)$. This finding $\overrightarrow{\text { is in }}$ accordance with those obtained by Imas and Sheva (2000).

The results presented in Table (6) show that there were no significant interactions between soil cultural treatments, S-application and Nfertilization levels on soil properties after summer maize of 2010 harvested.

\section{References}

Abd El-Halim, Z.; O. Niemeläinen; I. A. Hanna and A. M. Rammah. 2001. Carry-over effect in forage rotations on newly reclaimed sandy soil in Egypt. Egypt - Finland Agricultural Research Project. http://www.internationalgrasslands .org.

Abd El-Qahar and B. Ahmad. 2016. Effect of nitrogen and sulfur on maize hybrids yield and postharvest soil nitrogen and sulfur. 
Sarhad Journal of Agriculture, 32(3): 239-251.

Abdo, A. I. E.; K. F. Moussa; A. A. Sheha and S. A. Abd El-Bary. 2010. Effect of sulfur and organic matter application on wheat plant cultivated in sandy soil. Zagazig J. Agric. Res., 37(5) 1145-1159.

Abo-Elela, E. G. Y. 2002. The dynamic changes in chemical and mineralogical characteristics of calcids soils as affected by natural soil amendments. Ph. D. Thesis, Dept. of Soils and Water. Fac. Agric., Ain Shams Univ., Egypt.

Ailincai, C.; G. Jitareanu; D. Ailincai and A. Balan. 2010. Influence of some organic residues on wheat and maize yield and eroded soil fertility. Cercetari Agronomice în Moldova Vol. XLIII, No. 1 (141): 5-16.

Ali, M. M. A. 2008. The use of some microbial and agricultural treatments for improving productivity of sandy calcareous soils. M. Se. Thesis, Dept. of Soils and Water, Assiut University. Egypt.

Attia, K. K. and M. M. El - Dsouky. 1996. Effect of elemental sulfur and inoculation with Thiobacillus, organic manure and nitrogen fertilization on wheat. Assiut. J. Agric. Sci., 27 (4): 191- 206.

Awadalla, A. A.; M. M. Salib and S. P. Ibrahim. 2003. Response of maize yield grown on calcareous soil to some organic and inorganic amendments under irrigation with saline soil drainage water. Egypt. J. Appl Sci. 18 (3): 366-381.

Dendooven, L.; L. Patino-Zúnigaa, N. Verhulst, M. Luna-Guido, R. Marsch and B. Govaerts. 2012. Global warming potential of agricultural systems with contrasting tillage and residue management in the central highlands of Mexico.
Agriculture, Ecosystems and Environment 152: 50-58.

Eisa, S. A.; Sh. El-Borhamy and A. ElBasouny. 2003. Efficiency of mineral fertilizers and elemental sulfur application for maize grown on calcareous soil. Egypt. J. Appl. Sci., 18 (12B): 793-804.

El-Afandy, K. T.; A. A. Abdel-Ati and M. A. Mohamed. 2007. Effect of nitrogen, phosphorus and seeding rates on wheat production and weed control in Siwa oasis. J. Agric. Sci. Mansoura Univ., 32 (8): 6099-6111.

Ghimire, R.; S. Lamichhane; B. S. Acharya; P. Bista and U. M. Sainju. 2016. Tillage, crop residue, and nutrient management effects on soil organic carbon sequestration in rice-based cropping systems: A review. Journal of Integrative Agriculture, 15(0): 1-16.

Hassanein, M. K.; M. A. Abdrabbo and A. A. Farag. 2007. Effect of different nitrogen levels on productivity of three maize hybrids fertigation. Arab Univ. J. Agric. Sci., Ain Shams Univ., Cairo, 15 (2): 361368.

Heydarnezhad, F.; P. Shahinrokhsar; H. S. Vahed and H. Besharati. 2012. Influence of elemental sulfur and sulfur oxidizing bacteria on some nutrient deficiency in calcareous soils. International J. Agric. Crop Sci., 4 (12): 735-739.

Huang Y.; J. Zou; X. Zheng; Y. Wang and $\mathrm{X}$. Xu. 2004. Nitrous oxide emissions as influenced by amendment of plant residues with different C: $\mathrm{N}$ ratios. Soil Biol. Biochem., 36: 973-981.

Imas, P. and B. Sheva. 2000. Integrated nutrient management for sustaining crop yields in calcareous soils. Presented at GAU-PRII-IPI National Symposium on: Balanced nutrition of groundnut and other 
field crops grown on calcareous soils of India. September 19-22, 2000. Junagadh, Gujarat, India.

Jackson, M. L. 1973. Soil Chemical Analysis. Prentice-Hall, Inc. Englewood Cliffs, N.J. New Delhi, India.

Jaliya, M. M.; Sani, B. M.; Sani, Y. A.; Babaji; B. A. and A. M. Zongoma. 2016. Effect of nitrogen and sulfur nutrient ratios on the levels of protein content in maize grains. Sky Journal of Agricultural Research 5(2): 29-33.

Javadianfar, R and S.A. Siadat. 2013. Investigation on effect of wheat residue management using different tillage and nitrogen fertilizer on maize yield in the north of Khuzestan. Intl. J. Agric. Crop Sci.5 (15): 1719-1724.

Khadr, M. S.; R. Abo-El-Enein; A. Abd El-Shafy; F. A. Zahran and A. A. Zohry. 2004. Substantiality of soil fertility status after 3-yeat crop rotation in sandy soils in Egypt. Egypt. J. Agric. Res., 82(2): 475491.

Klute, A. 1986. Methods of soil analysis. Part-1. Physical and mineralogical methods. 2nd Edition American Society of Agronomy, Madison, Wisconsin, USA.

Kravchenko, A. G. and K. D. Thelen. 2007. Effect of winter wheat crop residue on no-till corn growth and development. Agron. J. 99: 549555.

Kumar, K. and J. Prasad. 2014. Long term effect of residual zinc and crop residue on yield, and uptake of micronutrients in rice in calcareous soil. Annals of Plant and Soil Research 16(1): 64-67.

Millar, N. and E. M. Baggs. 2004. Chemical composition, or quality, of agro forestry residues influences $\mathrm{N}_{2} \mathrm{O}$ emissions after their addition to soil. Soil Biol. Biochem., 36: 935-943.

Mohammad, W.; S. Shehzadi, S. M. Shah and Z. Shah. 2010. Effect of tillage and crop residues management on mungbean (vigna radiata L. wilczek) crop yield, nitrogen fixation and water use efficiency in rainfed areas. Pak. J. Bot. 42(3): 1781-1789.

Mohammad, W., S. M. Shah., S. Shehzadi, S. A. Shah. 2012. Effect of tillage, rotation and crop residues on wheat crop productivity, fertilizer nitrogen and water use efficiency and soil organic carbon status in dry area (rainfed) of north-west Pakistan. J. Soil Sci. \& Plant Nutr., 12 (4): 715-727.

Monsefi, A; A. R. Sharmab; N. Rang Zanc; U. K. Beherad and T. K. Dasd. 2014. Effect of tillage and residue management on productivity of soybean and physicochemical properties of soil in soybean-wheat cropping system. Intern. J. Plant Produ., 8 (3).15-25.

Parkinson, J. A. and S. E. Allen. 1975. A wet oxidation procedure suitable for the determination of nitrogen and mineral nutrients in biological materials. Commun. Soil Sci. Plant Analysis, 6: 1- 11.

Rahman, S. 2004. Yield and nutrient uptake by wheat as influenced by tillage and crop residues. M.Sc. Thesis, Depart. Agric. Chemistry, Bangladesh Agric. Univ.

Ray, R. W. and K. M. Spider. 2000. Sulfur nutrition of maize in four regions of Malawi. Agron. J., 92: $649-656$.

Safwat, M. S. A.; M. A. Sherif; O. A. O. Saad; E. A. Abdel-Bary and M. A. El-Mohandes. 2003. Recycling of crop residues for sustainable crop production in a wheat-peanut rotation system. In: Management of crop residues for sustainable crop 
production. pp: 179- 192. Joint FAO/IAEA Division of Nuclear Techniques in Food and Agriculture. Printed by the IAEA in Austria.

Sepahvand, H. and M. Mehranzadeh. 2014. The effect of tillage methods and wheat residue managements on soil physical properties and maize yield. Annals of Biological Research, 2013.4 (6):163-169.

Singh, H. 1995. Nitrogen mineralization, microbial biomass and crop yield as affected by wheat residue placement and fertilizer in a semiarid tropical soil with minimum tillage. J. Appl. Ecol. 32, 588595.(aop Mohammed)

Soleymani, A.; M. H. Shahrajabian and M. Khoshkharam. 2016. The impact of barley residue management and tillage on forage maize. Romanian Agricultural Research, NO. 33: 161-167.

Steel, R. G. D. and J. H. Torrie. 1982. Principals and Procedures of Statistics. A Biometrical Approach. Mc Graw Hill Book Company, New York. USA.

Verma, N. K. and B. K. Pandey. 2013. Effect of varying rice residue management practices on growth and yield of wheat and soil organic carbon in rice- wheat sequence. Agric. and Veterinary Sci. Volume 13 Issue 3 Version 1.0.

Zhang, J.; G. Bo; Z. Zhang; F. Kong, Y. Wang and G. Shen. 2016. Effects of straw incorporation on soil nutrients, enzymes, and aggregate stability in tobacco fields of China. Sustainability, 8 (710): 1-12. 
تأثير بعض المعاملات الزراعية، إضافة الكبريت العنصري و التسميد النيتروجينى على إنتاجية

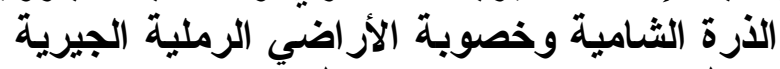

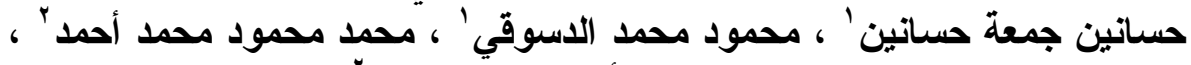

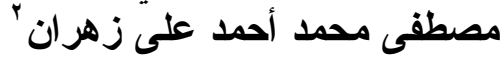

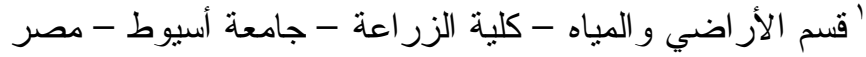

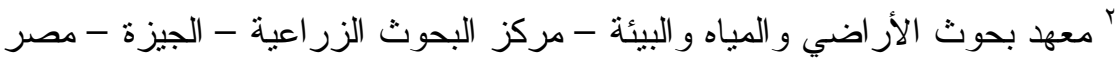

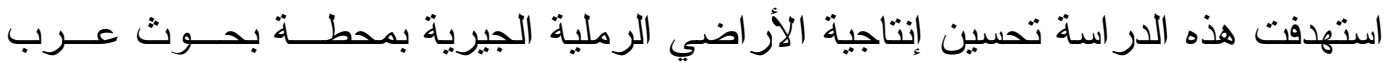

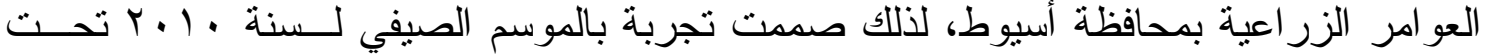

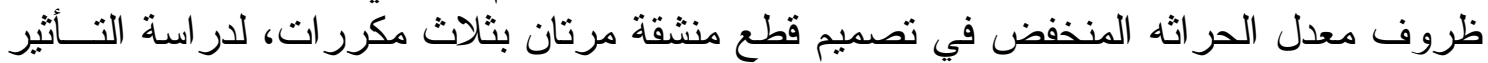

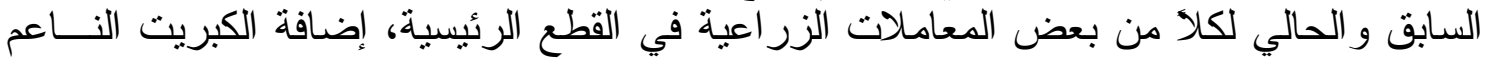

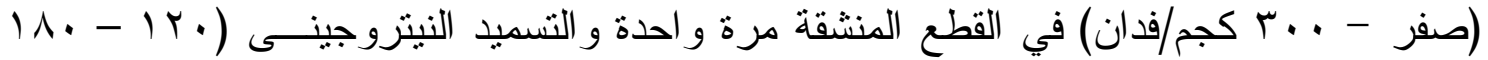

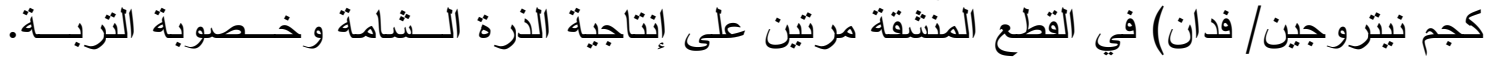

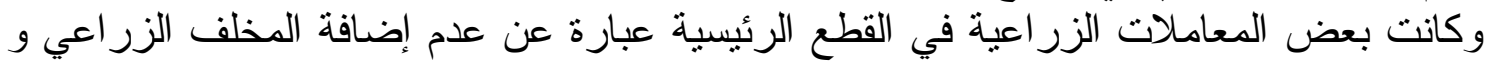

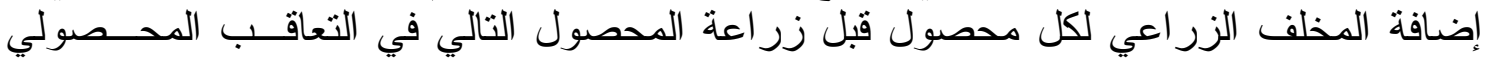
طبقا لاثتين من التعاقبات المحصولية كالتالي:-

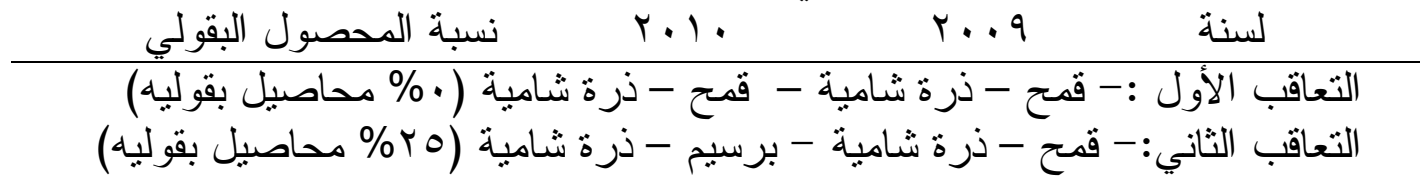

أظهرت النتائج أن استخدام معاملة التعاقب المحصولي الثاني (قمح - ذرة شامية - برسيم

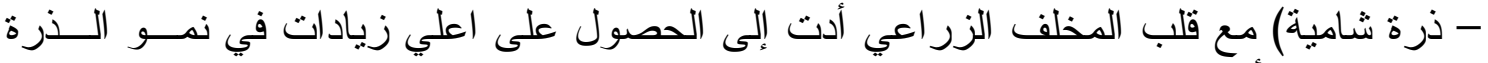

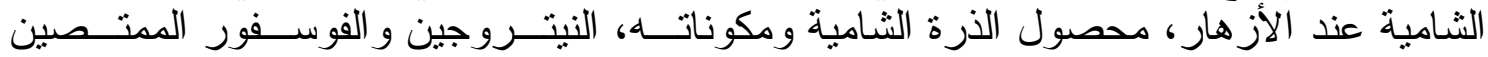

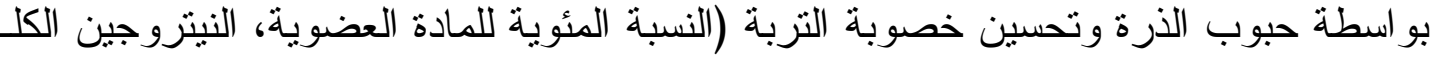

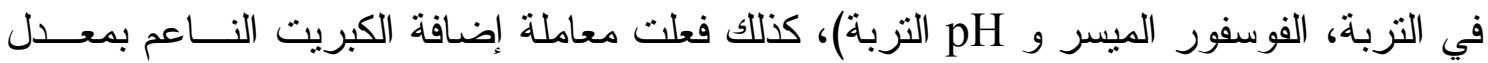

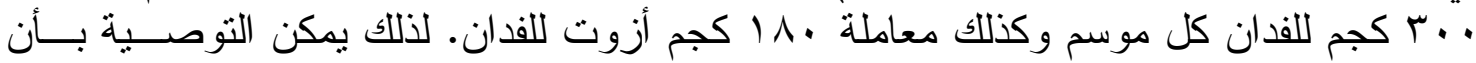

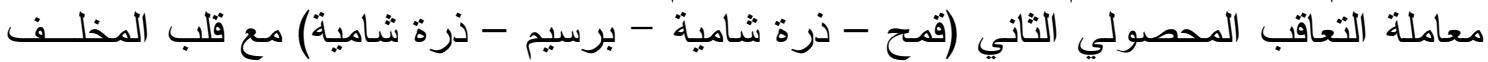

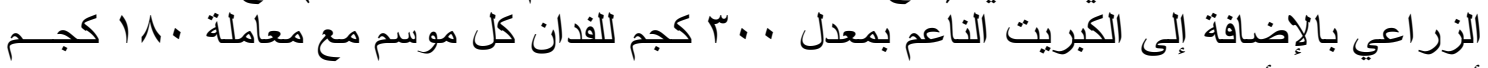
أزوت للفدان أدت إلى الحصول على اعلي إنتاجية للذرة الثامية وتحسين خصوبة التزبة الرملية الجيرية. الكلمات الدالة: التعاقب المحصولي، مخلفات المحاصيل، الكبريت العنــصري، التـسميد النيتروجينى، إنتاج الذرة الثنامية، الأر اضي الرولية الرملية الجيرية. 